\title{
Peran Imunoterapi pada Alergi Sengatan Lebah
}

\author{
Ahmad Faisal, H.M. Sjabaroeddin Loebis
}

Lebah termasuk famili Apidae dari ordo Hymenoptera dari kelas Insekta. Alergi akibat sengatan lebah dapat berupa reaksi lokal maupun sistemik yang dapat menimbulkan efek ke berbagai organ sampai menyebabkan kematian. Imunoterapi adalah pengobatan dengan cara menyuntikkan alergen kepada pasien dengan tujuan mengurangi atau mengeliminasi respon alergi. Imunoterapi alergi sengatan lebah diindikasikan pada keadaan anafilaksis yang disebabkan oleh sengatan lebah, distres jantung dan paru setelah sengatan, adanya IgE spesifik terhadap bisa lebah, kemungkinan terpajan ulang terhadap lebah, serta kesanggupan dari pasien. Imunoterapi alergi sengatan lebah terbukti efektif dan bermanfaat pada penanganan alergi sengatan lebah.

Kata kunci: alergi, sengatan lebah, imunoterapi

S engatan lebah dapat menimbulkan reaksi alergi dengan gejala klinik berupa reaksi lokal atau sistemik. Reaksi lokal berupa rasa nyeri, bengkak dan kemerahan di sekitar tempat sengatan. Reaksi sistemik berupa reaksi yang melibatkan berbagai organ sampai reaksi anafilaksis yang dapat menyebabkan kematian. ${ }^{1}$ Kematian akibat sengatan lebah dilaporkan 40 sampai 50 kasus per tahun di Amerika Serikat. Prevalensi reaksi alergi akibat sengatan lebah bervariasi antara 0,4 sampai $4 \%$ bahkan lebih, dengan angka mortalitasnya berkisar antara 0,09 sampai 0,45 per sejuta populasi setiap tahun. ${ }^{2}$ Dilaporkan terjadinya reaksi anafilaksis selama 5 tahun pengamatan, 15\% dari seluruh kasus disebabkan sengatan lebah. ${ }^{3}$ Namun belum diperoleh angka laporan kasus tersebut di Indonesia.

Manifestasi alergi akibat sengatan lebah bergantung pada pembentukan antibodi terhadap

\footnotetext{
Alamat korespondensi:

Dr.H.M. Sjabaroeddin Loebis, Sp.A(K)

Bagian Ilmu Kesehatan Anak FK USU RS Adam Malik,

Jl Bunga Lau No.17 Medan 697.Tel (061) 8361721. Fax.(061) 8361721.

Dr. Ahmad Faisal PPDS IKA FK - USU / RSHAM,

Bagian Ilmu Kesehatan Anak, Medan
}

substansi antigen pada bisa lebah. Gambaran klinis dapat berupa reaksi hipersensitifitas tipe lambat atau reaksi hipersensitifitas tipe cepat yang dapat mengancam kehidupan dan memerlukan penanganan yang tepat dan cepat. ${ }^{1-3}$

\section{Klasifikasi lebah}

Lebah merupakan ordo Hymenoptera dari kelas insekta, ${ }^{4,5}$ dibagi atas 2 famili yakni Apidae dan Vespidae. Famili Apidae ini terdiri dari beberapa macam spesies di antaranya lebah madu (honey bee), bumble bee serta lebah Afrika (African bee). Dari familli Vespidae terdiri dari penyengat, tawon, dan semut api. ${ }^{4,5}$ Alat penyengat lebah berada pada bagian bawah dari abdomen, terdiri dari kantung yang berisi bisa melekat pada duri penyengat. Jika terjadi sengatan maka kantung itu berkontraksi dan bisa dialirkan ke dalam tubuh korbannya. ${ }^{6}$ Lebah madu Afrika yang disebut lebah pembunuh, masuk ke Amerika Serikat di daerah Texas Selatan, kemudian menyebar ke Arizona dan California dan terus menyebar ke daerah yang beriklim tropis. Bisanya berisi unsur yang sama dengan lebah madu lainnya, hanya mereka lebih agresif menyerang manusia. ${ }^{6,9}$ 
Alergen utama pada bisa lebah terdiri dari fosfolipase A2, hialuronidase, substansi dengan berat molekul besar dengan aktifitas fosfatase asam, dan mellitin. ${ }^{5-8}$ Alergen dari famili vespidae terdiri dari fosfolipase, hialuronidase dan suatu protein yang dikenal sebagai antigen- 5 yang biasanya terdapat pada sejenis tawon.,

\section{Patogenesis}

Terdapat berbagai mekanisme timbulnya alergi setelah terjadi sengatan lebah. Pada reaksi yang ringan biasanya terjadi hipersensitifitas tipe lambat (delayed hypersensitivity), ${ }^{4}$ sedangkan reaksi yang berat terjadi akibat hipersensitifitas tipe cepat (immediate hypersensitivity reaction). ${ }^{4,5,10}$ Alergen yang dapat menimbulkan reaksi hipersensitifitas tersebut berasal dari berbagai jenis bisa lebah. ${ }^{10}$ Reaksi hipersensitifitas tipe lambat atau reaksi tipe IV disebut juga cell mediated immunity (CMI), delayed type hypersensitivity (DTH) contohnya reaksi tuberkulin timbul lebih dari 24 jam setelah tubuh terpajan dengan antigen. Reaksi terjadi karena respons sel $\mathrm{T}$ yang sudah disensitisasi terhadap antigen bisa, sebagai akibatnya sel $\mathrm{T}$ melepaskan limfokin antara lain macrophage inhibition factor (MIF) dan macrophage activating factor (MAF). Makrofag yang diaktifkan dapat menimbulkan kerusakan jaringan. ${ }^{11}$

Reaksi hipersensitifitas tipe cepat disebut juga reaksi hipersensitifitas tipe I atau reaksi anafilaksis atau reaksi alergi adalah proses akut yang dapat menimbulkan kematian akibat dari pelepasan mediator dengan cepat yang berasal dari sel mast atau basofil sebagai interaksi antara alergen dengan IgE. ${ }^{10,11}$ Istilah ana berasal dari kata Yunani yang berarti "jauh dari" dan phylaxis yang berarti "perlindungan". Istilah tersebut adalah kebalikan dari istilah profilaksis. Urutan kejadian reaksi tipe I adalah sebagai berikut antigen merangsang sel B untuk membentuk IgE dengan bantuan sel Th. Imunoglobulin E kemudian diikat oleh mastosit/ basofil melalui reseptor Fc. Apabila tubuh terpajan ulang dengan antigen yang sama, maka antigen tersebut akan diikat oleh IgE yang sudah ada pada permukaan mastosit/basofil. Akibat ikatan antigenIgE, mastosit/basofil mengalami degranulasi dan melepas mediator yang dapat menimbulkan gejala pada reaksi hipersensitifitas tipe I. ${ }^{10-12}$

\section{Gejala klinis}

Setelah mengalami sengatan lebah maka akan terjadi reaksi lokal pada kulit yang biasanya berlangsung singkat. Reaksi normal akan menimbulkan nyeri, bengkak, dan kemerahan pada daerah sengatan. Kadang-kadang timbul reaksi lokal yang luas pada tempat sengatan, namun hal ini akan hilang dalam waktu 2 sampai 3 hari. Lebah dan tawon meninggalkan alat sengat pada kulit korbannya. ${ }^{1,5,6,13}$

Pada reaksi hipersensitifitas tipe lambat ditandai dengan timbulnya lesi yang mengeras bila disertai papul yang persisten dan berkembang menjadi hiperpigmentasi, bahkan sering menimbulkan ekskoriasi dan krusta. Rasa gatal dapat ringan sampai berat, bersifat sementara atau menetap. Cekungan pada bagian sentral sering terlihat tetapi akan menghilang kemudian. ${ }^{4}$ Reaksi anafilaksis dimulai dalam beberapa detik atau beberapa menit setelah terjadinya sengatan. Gejala pada kulit berupa rasa gatal, kemerahan, urtikaria, dan angioedema. Gejala kardiovaskular berupa hipotensi disertai sinus takikardi atau bradikardi, yang menunjukkan tipe reaksi vasovagal. Gejala respirasi berupa bronkospasme (dengan mengi pada ekspirasi), edem laring (stridor inspirasi) atau timbulnya dispne dengan suara napas yang normal. Gejala sistim pencernaan berupa kaku pada usus, muntah dan diare (kadang-kadang berdarah), dan kaku pada uterus. Reaksi yang berat dapat disertai perasaan

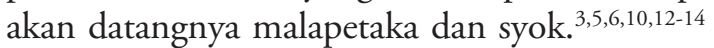

Akibat lanjut dari sengatan lebah dapat menimbulkan komplikasi ke berbagai organ. Dilaporkan adanya kasus neuropati optikus setelah mengalami sengatan lebah, ditandai dengan hilangnya kemampuan visual, perdarahan dan edem pada diskus optikus dan skotoma sentralis. ${ }^{15}$ Komplikasi sengatan lebah juga dapat mengenai organ ginjal dan hati. Dilaporkan terjadinya kasus gagal ginjal akut dan gangguan hati akibat sengatan lebah, yang menyebabkan timbulnya hipotensi, hemolisis intravaskular, rhabdomyolisis sebagai akibat efek toksik dari bisa lebah. ${ }^{16}$

\section{Diagnosis}

Diagnosis alergi sengatan lebah ditegakkan berdasarkan timbulnya gejala dan tanda akibat alergi sengatan lebah disertai ditemukannya lebah sebagai penyebab. Pada daerah sengatan akan disertai timbulnya reaksi lokal dan 
dapat ditemukan alat sengat lebah pada kulit pasien. Gejala yang timbul setelah sengatan menunjukkan adanya alergi berupa reaksi tipe lambat sampai paling berat timbulnya syok pada reaksi anafilaksis. ${ }^{1,5,6,10,13}$

Uji kulit dengan antigen berupa bisa lebah digunakan untuk mengenali bisa yang spesifik yang bertanggung jawab pada proses sensitisasi tersebut. ${ }^{5,6,10,13,14,17}$ Ada 5 jenis bisa secara komersial telah tersedia, yaitu bisa terhadap lebah madu, yellow jacket, yellow hornet, white faced hornet dan Palister wasps (Miles, Inc, Pharmaceutical, Spokane, Wash, dan ALKLaboratories, Wallingford, Conn). Beberapa laboratorium sedang mengembangkan berbagai jenis bisa lainnya. ${ }^{6,17}$

Uji kulit Prick dilakukan dengan menggunakan bisa lebah pada konsentrasi $1 \mathrm{ug} / \mathrm{ml}$, dengan konsentrasi yang sama diberikan pelarut kontrol (Sorenson's solution) yang mengandung 0,5\% serum albumin dan $0,4 \%$ fenol. Hasilnya dibaca dan dicatat setelah 15 menit. Jika respon uji Prick negatif dilakukan uji kulit intradermal dengan menggunakan bisa pada konsentrasi $0,2 \mathrm{ug} / \mathrm{ml}$ dan $1 \mathrm{ug} / \mathrm{ml}$ pada tempat yang terpisah sebanyak $0,03 \mathrm{ml}$. Histamin dan pelarut kontrol diinjeksikan secara intradermal. Hasilnya dibaca setelah 15 menit, dan dicatat timbulnya pembengkakan serta kemerahan. Reaksi segera yang timbul pada uji kulit dengan konsentrasi bisa $<0,1$ sampai $1,0 \mathrm{ug} / \mathrm{ml}$ dinyatakan positif dan penderita tersebut mempunyai $\operatorname{IgE}$ spesifik terhadap bisa tersebut. ${ }^{6,17}$

Pemeriksaan invitro untuk mendeteksi antibodi IgE terhadap bisa lebah dapat dilakukan dengan cara radio allergosorbent test (R.A.S.T). ${ }^{5,6,10,13,14}$ Pemeriksaan RAST telah dikembangkan untuk menilai diagnosis hipersensitifitas akibat sengatan lebah dengan menggunakan alergen yang telah dimurnikan berasal dari bisa lebah. ${ }^{18}$ Dalam tekhnik ini antigen mulamula diikat benda padat dari selulosa. Imunoglobulin E yang diikat kemudian dapat ditemukan kembali dengan anti-IgE yang bertanda radioaktif. Radioaktifitas yang diikat kemudian dapat dihitung dengan gamma counter. ${ }^{19}$

\section{Pengobatan}

Pada reaksi lokal diperhatikan apakah lebah meninggalkan sengatnya pada kulit pasien. Singkirkan sengat tersebut dengan menggunakan penjepit atau dengan kuku jari. Jangan lakukan penekanan pada sengat tersebut karena dapat mengakibatkan pelepasan bisa lebih banyak kedalam kulit. ${ }^{1,14}$ Untuk mengurangi rasa nyeri dan pembengkakan cukup digunakan kompres dingin, tetapi reaksi lokal yang luas membutuhkan pengobatan dengan antihistamin dan kortikosteroid (prednison). ${ }^{1,4-6,10,13}$

Jika terjadi reaksi anafilaksis, obat pilihannya adalah epinefrin dalam larutan 1:1000, diinjeksikan secara intramuskular atau subkutan dengan dosis 0.2$0.5 \mathrm{ml}$ atau $0.01 \mathrm{ml} / \mathrm{kg}$ berat badan. Pemberiannya dapat diulangi dalam 15 menit jika masih diperlukan. 1,2,5,6,10,12-14 Pada reaksi berat yang persisten dapat digunakan infus intravena epinefrin $(1: 10.000)$ dengan dosis $0.1 \mathrm{ug} / \mathrm{kg} /$ menit dengan pemantauan jantung yang ketat untuk mempertahankan tekanan sistolik $80 \mathrm{mmHg}$. Jika hipotensi dan syok tidak respon terhadap epinefrin, harus diberikan cairan intravena dengan larutan garam isotonis $(\mathrm{NaCl} 0.9 \%)$ secara cepat (>100 ml/menit). Pasien diletakkan pada posisi Trandelenberg dengan meninggikan kedua kakinya., ${ }^{5}, 12$ Timbulnya edema laring mungkin menyulitkan pemasangan selang endotrakeal maka diperlukan tindakan bedah trakeostomi untuk mempertahankan saluran napas. Tindakan krikotirotomi diperlukan jika belum dapat dilakukan trakeostomi. ${ }^{12,14}$

Pada keadaan timbulnya obstruksi bronkus penanganannya sama seperti asma bronkial. Diberikan aminofilin $6 \mathrm{mg} / \mathrm{kg}$ berat badan dalam $20 \mathrm{ml}$ dextrose $5 \%$ secara intravena dalam masa 10 15 menit sebagai dosis awal, dilanjutkan dengan $0.9 \mathrm{mg} / \mathrm{kg} / \mathrm{jam}$ sebagai dosis pemeliharaan. Jika bronkospasme menetap diberikan bronkodilator $\beta$ adrenergik secara nebulisasi. Jika terdapat tanda gagal napas dengan nilai $\mathrm{PaCO} 2>65 \mathrm{mmHg}$ diperlukan intubasi endotrakeal dan ventilasi mekanik. ${ }^{12,14}$ Pada reaksi tipe lambat yang terjadi kemudian cukup diberikan antihistamin oral seperti difenhidramin 1-2 mg/kg BB. Kombinasi antagonis $\mathrm{H} 1$ dan antagonis $\mathrm{H} 2$ seperti simetidin dengan dosis $4 \mathrm{mg} / \mathrm{kgBB}$ memberikan hasil yang lebih baik. ${ }^{1,2,5,6,12,14}$ Pengobatan topikal dengan krem kortikosteroid kurang efektif dan penggunaan antihistamin topikal dapat berpotensi timbulnya sensitisasi dan tidak berperan pada pengobatan alergi sengatan lebah. ${ }^{4}$ Untuk pengobatan jangka panjang pada pasien dengan alergi sengatan lebah dapat dilakukan pengobatan secara imunologis yang efektif untuk mencegah reaksi alergi akibat sengatan lebah. ${ }^{5,6}$ 
Sari Pediatri, Vol. 6, No. 3, Desember 2004

\section{Imunoterapi pada alergi sengatan lebah}

Desensitisasi terhadap alergi adalah suatu bentuk pengobatan dengan cara alergen diinjeksikan kepada pasien dengan tujuan mengurangi atau mengeliminasi respons alergi. Istilah yang sering digunakan adalah imunoterapi alergi, hiposensitisasi, dan terapi injeksi alergen. Tindakan ini paling sering dilakukan pada penyakit yang dimediasi antibodi $\mathrm{IgE}$, namun dapat pula digunakan pula pada penyakit alergi lainnya. . $2,5,6,10,20$

Imunoterapi sebagai pengobatan penyakit alergi telah dilakukan pada awal dekade abad ke 20 (1911) saat Noon dan Freeman di St Mary Hospital, London, menggunakan ekstrak serbuk sari (pollen) pada pengobatan penyakit hay fever. Imunoterapi ini telah banyak dilakukan di Amerika Utara juga di Inggris. Bertahun-tahun hal ini dilakukan sebagai pilihan pengobatan penyakit rinitis alergika dan asma. ${ }^{20-23}$

Sejumlah uji klinik telah dilakukan untuk menentukan efektifitas imunoterapi ini pada rinitis alergika dan reaksi anafilaksis terhadap bisa hymenoptera. Desensitisasi juga telah dilakukan terhadap alergi penisilin dan insulin. Desensitisasi secara oral dilaporkan telah berhasil pada pengobatan drug induced cutaneous eruption. ${ }^{20,21}$

Mekanisme kerja dari imunoterapi alergi masih belum begitu jelas. Perubahan imunologi yang bertanggung jawab mengurangi timbulnya gejala alergi masih belum pasti. Teori yang dipercaya adalah imunoterapi alergi menginduksi produksi antibodi IgG terhadap alergen spesifik (disebut blocking antibody), tetapi hal ini masih kontroversial. Imunoterapi akan menyebabkan perubahan pada sekresi sitokin yang mana terjadi peningkatan produksi IL-10 yang akan meningkatkan respon dari Th-1. Respon Th-1 juga dapat dibangkitkan oleh sitokin lainnya yaitu melalui IL-15 dan IL-2. Peningkatan peran sitokin tersebut mengakibatkan supresi dari IgE dan meningkatkan produksi IgG4 yang bersifat proteksi. ${ }^{5,6,20,21,24}$

Imunoterapi terhadap bisa lebah diindikasikan pada anafilaksis yang disebabkan oleh sengatan lebah, adanya distres jantung dan paru setelah terkena sengatan lebah, adanya bukti IgE spesifik terhadap bisa lebah, kemungkinan berlanjutnya terpajan pada sengatan lebah, dan kesanggupan pasien. ${ }^{20,21}$

Imunoterapi alergi dikontraindikasikan pada keadaan seperti, terdapatnya penyakit medik atau imunologis yang nyata, pasien mendapat obat yang mengganggu pengobatan anafilaksis ( $\beta$ bloker atau obat penghambat adrenergik), kurangnya keinginan atau motivasi pasien dan kehamilan. Imunoterapi ini tidak dianjurkan pada anak usia $<5$ tahun, pasien dengan riwayat asma perenial kronik dan pasien dengan dermatitis berat. ${ }^{20,21}$

Sebagai alergen digunakan cairan ekstrak yang mengandung bisa lebah, diinjeksikan berulang ulang sampai tercapai dosis maksimal $(100 \mathrm{ug} / \mathrm{ml})$. Alergen tersedia dengan konsentrasi $0,1 \mathrm{ug} / \mathrm{ml}, 1 \mathrm{ug} / \mathrm{ml}, 10$ $\mathrm{ug} / \mathrm{ml}$ dan $100 \mathrm{ug} / \mathrm{ml}$ dilarutkan dalam larutan albumin $0,5 \%$ dan fenol (0,4\%). ${ }^{6,20,21}$ Bisa lebah diinjeksikan secara subkutan dimulai dari konsentrasi yang terendah $0,1 \mathrm{ug} / \mathrm{ml}$ dan dinaikkan dosis tersebut satu atau dua kali setiap minggu sampai dosis maksimal tercapai $(100 \mathrm{ug} / \mathrm{ml})$ yang ditandai dengan peradangan di sekitar tempat penyuntikan. Fase inisial atau induksi dicapai dalam waktu 3 bulan (konvensional). Jadwal induksi pada rush imunoterapi dicapai dalam masa tiga sampai empat hari, sedangkan ultrarush dalam masa satu hari. Dengan cara induksi ini dapat dihemat waktu tanpa efek samping yang berarti. Namun pasien harus dirawat di rumah sakit untuk mengatasi kemungkinan terjadinya efek samping yang berat. Pasien harus dimonitor dengan hati-hati terutama dalam 10 sampai 20 menit setelah bisa diinjeksikan. ${ }^{5,6,20,21}$

Dosis pemeliharaan dilanjutkan sekali setiap bulannya sampai dengan masa 3 tahun. 5,6,20,21,25-27 Biasanya perbaikan tampak nyata setelah 3 tahun pengobatan, sehingga pemberian imunoterapi dapat dihentikan dan diobservasi adanya gejala rekuren. Beberapa kasus dilaporkan setelah bertahun-tahun mendapat pengobatan imunoterapi tidak menunjukkan hasil yang bermanfaat. Jadi imunoterapi tidak perlu dilanjutkan apabila tidak ditemukan perbaikan dalam masa 2 tahun pengobatan..$^{25-27}$

Injeksi imunoterapi dapat menginduksi berbagai efek samping lokal maupun sistemik yang terjadi cepat atau lambat. Reaksi anafilaksis jarang terjadi dan biasanya timbul dalam 15 sampai 20 menit setelah injeksi. Efek samping yang terjadi setelah 60 menit biasanya ringan dan tidak memerlukan intervensi khusus. Itulah alasan dianjurkannya observasi selama 60 menit sesudah injeksi dianggap cukup mendeteksi semua efek samping serius yang membutuhkan pengobatan. ${ }^{20,21,25,28}$ Efek samping yang ringan berupa rasa gatal, urtikaria dan pembengkakan di sekitar tempat penyuntikan. Apabila timbul efek samping yang berat maka diperlukan pengurangan dosis sampai $50 \%$ pada penyuntikan berikutnya. ${ }^{20,21}$ 
Pengobatan pasien alergi sengatan lebah dengan imunoterapi dilaporkan sangat efektif mengurangi risiko anafilaksis yang disebabkan sengatan lebah. Valentine MD melaporkan efektifitas sampai dengan 97 persen dalam mencegah reaksi sistemik akibat sengatan lebah. ${ }^{29}$ Canadian Society of Allergy and Clinical Immunology telah merekomendasikan imunoterapi ini pada penyakit alergi sengatan lebah. ${ }^{30}$ Di Inggris dan Amerika Serikat imunoterapi telah luas digunakan sebagai pengobatan pilihan pada penyakit alergi. ${ }^{20,21}$

\section{Kesimpulan}

Diagnosis alergi sengatan lebah berdasarkan gejala klinis akibat sengatan lebah berupa reaksi lokal atau sistemik, ditemukannya lebah sebagai pelaku, uji kulit intradermal serta dibuktikannya keterlibatan IgE spesifik dengan pemeriksaan radioalergosorbent test (R.A.S.T). Pengobatan alergi sengatan lebah berupa penanganan reaksi anafilaksis, medikamentosa dengan antihistamin dan kortikosteroid serta pengobatan suportif akibat reaksi tipe cepat. Imunoterapi alergi efektif dan bermanfaat pada penanganan alergi sengatan lebah.

\section{Daftar Pustaka}

1. Curtis J. Insect sting anaphylaxis. Pediatr Rev 2000; 21:256.

2. Mingomataj E, Priftanji A, Qirko E, Thai Dinh Q, Fischer A, dkk. Specific immunotherapy in Albanian patients with anaphylaxis to hymenoptera venoms. BMC Dermatology 2002; 2:11.

3. Dibs SD, Baker MD. Anaphylaxis in children: A 5-year experience. Pediatrics 1997; 99:1-5.

4. Darmstadt GL. Arthropod bites and infestations. Dalam: Behrman RE, Kliegman RM, Jenson HB, penyunting. Nelson textbook of pediatrics. Edisi ke-16. Philadelphia: Saunders; 2000. h. 2043-7.

5. Ewan PW. Venom allergy. BMJ 1998; 316:1365-8.

6. Reisman RE. Insect stings. N Engl J Med 1994; 331:523-7.

7. Valentin E, Ghomaschi F, Gelb MH, Lazdunski M, Lambeau G. Novel human secreted phospholipase A2 with homology to the group III bee venom enzyme. Journal of Biological Chemistry 2000; 275:7492-6.
8. Akdis CA, Akdis M, Blesken T, Wymann D, Alkan SS, dkk. Epitop-spesific T cell tolerance to phospholipase $\mathrm{A} 2$ in bee venom immunotherapy and recovery by IL-2 and IL-15 in vitro. J Clin Invest 1996; 98:1676-83.

9. Schumacher MJ, Egen NB. Significance of Africanized bees for public health. Arch Intern Med 1995; 155:2038.

10. Valentine MD. Anaphylaxis and stinging insect hypersensitivity. JAMA 1992; 268:2830-3.

11. Bratawidjaja KG. Reaksi hipersensitifitas. Dalam: Imunologi dasar. Edisi ke-4. Jakarta: Balai Penerbit FKUI; 2001. h. 106-29.

12. Sly RM. Anaphylaxis. Dalam: Behrman RE, Kliegman RM, Jenson HB, penyunting. Nelson textbook of pediatrics. Edisi ke-16. Philadelphia: Saunders; 2000. h. 686-8.

13. Holve S. Envenomations. Dalam: Behrman RE, Kliegman RM, Jenson HB, penyunting. Nelson textbook of pediatrics. Edisi ke-16. Philadelphia: Saunders; 2000. h. 2174-8.

14. Terr AI. Anaphylaxis and urticaria. Dalam: Stites DP, Terr AI, Parslow TG, penyunting. Medical immunology. Edisi ke-9. Stamford: Appleton \& Lange; 1997. h. 409-18.

15. Maltzman JS, Lee AG, Miller NR. Optic neuropathy occurring after bee and wasp sting. Ophthalmology 2000; 107:193-5.

16. Thiruventhiran T, Goh BL, Leong CL, Cheah PK, Looi ML, Tan SY. Acute renal failure following multiple wasp stings. Nephrol Dial Transplant 1999; 14:214-7.

17. Yocum MW, Gosselin VA, Yunginger JW. Safety and efficiency of an accelerated method of venom skin testing. J Allergy Clin immunol 1996; 97:1424-5.

18. Sobotka AK, Adkinson NF, Valentine MD, Lichtenstein LM. Allergy to insect stings. IV.Diagnosis by radioallergosorbent test (RAST). J Immunol 1978; 121:2477-84.

19. Bratawidjaja KG. Pemeriksaan sistem imun. Dalam: Imunologi dasar. Edisi-4. Jakarta: Balai Penerbit FKUI; 2001. h. 275-305.

20. Terr AI. Allergy desensitization. Dalam: Stites DP, Terr AI, Parslow TG, penyunting. Medical immunology. Edisi ke-9. Stamford: Appleton \& Lange; 1997. h. 796-801.

21. AJ Frew on behalf of a British Society for Allergy and Clinical Immunology Working Party. Injection immunotherapy. BMJ 1993; 307:919-23. 
22. Adkinson NF, Eggleston PA, Eney D, Goldstein EO, Schuberth KC, Bacon JR dkk. A controlled trial of immunotherapy for asthma in allergic children. N Engl J Med 1997; 336:324-31.

23. Iliopoulos O, Proud D, Adkinson NF, Creticos PS, Norman PS, dkk. Effects of immunotherapy on the early, late, and rechallenge nasal reaction to provocation with allergen: change in inflammatory mediators and cells. J Allergy Clin Immunol 1991; 87:855-66.

24. Akdis CE, Blaser K. IL-10 induced anergy in peripheral $\mathrm{T}$ cell and reactivation by microenvironmental cytokines: two key steps in specific immunotherapy. The FASEB Journal 1999; 13:603-9.

25. Sly RM. Immunotherapy. Dalam: Behrman RE, Kliegman RM, Jenson HB, penyunting. Nelson textbook of pediatrics. Edisi ke-16. Philadelphia: Saunders; 2000. h. 660-2.
26. Reisman RE. Duration of venom immunotherapy: Relationship to the severity of symptoms of initial insect sting anaphylaxis. J Allergy Clin Immunol 1993; 92:831-6.

27. Mueller HL. Maintenance of protection in patients treated for stinging insect hypersensitivity: a booster injection program. Pediatrics 1977; 59:773-6.

28. Mosbech H, Muller U. Side effects of insect venom immunotherapy: results from an EAACI multicenter study. Allergy 2000; 55:1005-10.

29. Valentine MD, Schuberth KC, Sobotka AK, Graft DF, Kwiterovich KA, dkk. The value of immunotherapy with venom in children with alergy to insect stings. $\mathrm{N}$ Engl J Med 1990; 323:1601-3.

30. Canadian Medical Association. Guidelines for the use of allergen immunotherapy. Canadian Society of Allergy and Clinical Iimmunology. Can Med Assoc J 1995; 152:1413-9. 